\title{
Buried but unsafe - defoliation depletes the underground storage organ (USO) of the mesic grassland geophyte, Hypoxis hemerocallidea
}

\section{Craig D. Morris}

Agricultural Research Council - Animal Production (ARC-AP), c/o School of Life Sciences, University of KwaZulu-Natal, Private Bag X01, Scottsville 3209, Pietermaritzburg, South Africa. Correspondence: morris@ukzn.ac.za

\section{Abstract}

Mesic grasslands in South Africa (> $650 \mathrm{~mm} \mathrm{a}^{-1} \mathrm{MAP}$ ) are rich in herbaceous forbs, which outnumber grass species by more than 5 to 1 . Many of these forbs have underground storage units (USOs), such as thickened rootstocks, rhizomes, bulbs, or corms, that provide resources (non-structural carbohydrates, minerals, and water) enabling them to resprout after dry, frosty winters, and fire. However, despite their extensive biomass and reserves ostensibly protected underground, geophytic mesic grassland forbs can be severely depleted or extirpated by chronic trampling and grazing of their aerial parts by livestock. This study examined a possible explanation for forb demise in overgrazed grassland by investigating, in a pot trial, whether the growth of forbs and the size of their USOs are negatively affected by simulated green leaf loss. In a $2 \times 2$ factorial (clipped vs. unclipped $x$ spring regrowth in the dark vs. light), five replicate plants of Hypoxis hemerocallidea, a common mesic grassland forb that resprouts from a corm, were subject to six severe (clipped to $80 \mathrm{~mm}$ ) defoliations during the growing season and regrown in spring under full or restricted light to measure stored reserve contribution to regrowth. Defoliated plants were resilient to defoliation during the growing season, matching the total biomass production of unclipped plants, though cutting reduced the number of leaves by $\neg 60 \%$ and flowers by almost $85 \%$. Spring regrowth on stored reserves equalled that from reserves plus concurrent photosynthesis, indicating the value of USOs for regrowth. However, there was a marked carry-over effect of previous season defoliation, resulting in a one-third reduction in shoot growth and $40 \%$ fewer inflorescence in spring. Crucially, corm mass was more than halved by clipping. Above-ground spring growth was linearly related to corm mass. It was concluded that buried stored reserves are not protected by recurrent disturbance to aerial plant parts and that continued diminishment of USOs under chronic disturbance by overgrazing or frequent mowing would weaken and likely eventually kill plants, reducing 
forb species richness. Lenient management by infrequent summer mowing or grazing at moderate stocking rates combined with periodic rotational full season resting and dormantseason burning is recommend to maintain the USOs and vigour of forbs in mesic grassland.

Keywords: belowground biomass; biodiversity; fire; forbs; overgrazing

\section{Introduction}

Grasslands, including those in southern Africa (Cowling and Hilton-Taylor, 1997; Bond and Parr, 2010), are among the most speciose plant communities on the planet at point and patch scales (sub-metre to $100 \mathrm{~m}^{2}$ ), despite being subject to frequent and often intense disturbance by fire, grazing, or mowing (Wilson et al., 2012; Martorell et al., 2017). Most of the plant species diversity of mesic grassland in South Africa (> $650 \mathrm{~mm} \mathrm{a}^{-1} \mathrm{MAP}$ ) comprises herbaceous monocotyledonous and dicotyledonous herbaceous forbs (hereafter referred to as 'forbs'), which contribute more than $80 \%$ of the species richness (Morris, 2004; Uys et al., 2004). The diverse suite of forbs co-occurring with grasses in South African mesic grassland has coevolved with recurrent dry season (winter to early spring) fires fuelled by senescent grass phytomass accumulated in the growing season (Everson et al., 1988; Bond et al., 2003). Forbs resprout rapidly after a burn from buds on underground storage organs (USOs), such as woody rootstocks, bulbs, or corms (Uys, 2006; Zaloumis and Bond, 2016; Klimešová et al., 2019), that protect growing perennating buds from fire and frost while providing a store for energy for rapid regrowth of leaves and inflorescences in spring (Dafni et al., 1981; Clarke et al., 2013; Pausas et al., 2018; Lubbe et al., 2021). Consequently, mesic grassland forbs can consequently withstand frequent topkill by frost, fire, or mowing (Fynn et al., 2004; Morris et al., 2021). Investment in below-ground structures such as USOs does, however, render forbs vulnerable to soil disturbance: destruction of damage to USOs resulting from cultivation for cropping or afforestation can eliminate or severely reduce populations of grassland forbs (Bond and Zaloumis, 2016; Silveira et al., 2020).

Another type of disturbance inimical to mesic grassland forbs is overgrazing by livestock. Light to moderate levels of grazing can sustain forb populations (Joubert et al., 2017; 
Parrish, 2017) but heavy grazing, especially if relentless, can reduce plant species diversity and markedly transform species composition (O'Connor, 2005; Uys, 2006; Chamane et al., 2017a). Scott-Shaw and Morris (2015) reported that intense grazing can deplete up to $84 \%$ of the species richness of indigenous forbs. Frequent summer mowing can also be detrimental to certain forb species (Fynn et al., 2005; Valkó et al., 2012). The process whereby grazing animals and mowing can negatively impact mesic forb plants and eventually reduce their populations is not clear as the regenerative organs and energy supplies of such forbs are underground, out of the reach of the mouths and hooves of herbivores and the blades of mowers (Cole, 1995): only $20 \%$ of grassland biomass is above ground (Ottaviani et al., 2020). This study examines a possible indirect mechanism to explain the demise of forbs under grazing by testing whether repeated disturbance to the aboveground parts of a widespread mesic forb, Hypoxis hemerocallidea Fisch., C.A.Mey. \& AvéLall., has an impact on the size of its underground storage organ (a corm) and its ability to support resprouting in the following spring.

Only recently has the extent and degree of above-ground damage to forbs by grazing animals been quantified. Chamane et al. (2017b) reported that almost $90 \%$ of forbs in a mesic grassland stocked with cattle at a high density for a short period experienced partial or complete defoliation, tearing, or shredding of their stems and leaves. Abundant forbs have the greatest chance of being damaged, but some rare species also do not escape herbivory (Chamane et al., 2017b). Plant architecture appears to be an important determinant of what direct disturbance forb experience and how they respond to tissue damage by grazing and trampling. Forbs that are reduced or eliminated by chronic herbivory tend to have an erect growth habit, rendering them most exposed, and thus susceptible, to the actions of herbivores, whereas those that proliferate in overstocked grassland are typically prostrate hemicryptophytes that experience less damage to their above-ground tissues or to their buds that are held close to the ground (Uys, 2006; Cole, 1995; Chamane et al., 2017a; Morris and Scott-Shaw, 2019). Very few indigenous forbs can persist in the persistently overgrazed site, which are dominated mostly by non-native ruderal prostrate forbs and grazing-tolerant, course grasses (O'Connor, 2005; Morris and Scott-Shaw, 2019). Loss of photosynthetic leaf area through grazing, trampling, or mowing would immediately limit carbon sequestration, retarding total above-ground growth of forbs (Chamane et al, 
2019). Supply of photosynthates to USOs in geophytic forbs would also be curtailed, reducing the amount of non-structural carbohydrates (NSCs) available for maintenance, storage (Dafni et al., 1981; Chapin et al., 1990), and spring regrowth (Bayer, 1955; Tolsma, 2002; Werger and Huber, 2006; Martínez-Vilalta et al., 2016). Therefore, the negative effect of frequent defoliation in one season on above-and below-ground productivity could be carried over into the following season (White, 1973; Turner et al., 1993; Briske et al., 1996). Frequent herbivory over many seasons could eventually reduce the size and regenerative capacity of for USOs and their potential for long-term survival in heavily grassed mesic grassland swards (Chamane et al., 2019).

The hypothesis that repeated defoliation of aerial parts of a forb during a season would diminish the size of underground storage organs, resulting in reduced plant performance in the spring of the following season was tested in pot trial using $H$. hemerocallidea. It was predicted that frequent summer defoliation would: (1) reduce aerial plant production (leaves, inflorescences, and total phytomass) in the season of application, and (2) decrease corm mass as well as aerial biomass production in the subsequent spring. Restricted light conditions in spring were also imposed on defoliated and undefoliated control plants to force them draw fully on their stored reserves rather than jointly or solely on concurrent photosynthesis (Danckwerts and Gordon, 1990) for spring regrowth as a means of further assessing the effect of defoliation history on plant vigour (Wigley et al., 2021). It was predicted that previously defoliated plants would perform most poorly in the dark when drawing on reserves because of the legacy effect of frequent defoliation on diminishing the store of underground energy reserves available for spring regrowth.

\section{Methods}

\subsection{Study species}

Hypoxis hemerocallidea Fisch., C.A.Mey. \& Avé-Lall. is a long-lived perennial herbaceous geophyte widespread in mesic grassland, savanna and thicket in south-eastern, eastern, central, and northern South Africa as well as Lesotho, eSwatini, Botswana, Zimbabwe, and Mozambique (Williams et al., 2019; Mofokeng et al, 2020). Hairy, sickle-shaped leaves (110$600 \mathrm{~mm}$ in height, $10-15 \mathrm{~mm}$ wide) grow in three ranks, emerging from terminal buds on an underground corm (25-70 mm diameter; up to $500 \mathrm{~g}$ in weight) along with long stems bearing yellow-shaped flowers (6-16 per stem) that open and close daily (Pooley, 1998; 
Mofokeng et al., 2018). Leaves emerge first in spring and thereafter synanthously with flowers (Pooley, 1998; Lamont and Downes, 2011).

Hypoxis hemerocallidea is still currently abundant and of least conservation concern (Williams et al., 2019). However, extensive loss of grassland through land-use change (Jewitt et al., 2015) will reduce its future range while extensive harvesting of the corm for a wide range of traditional and commercial medicinal purposes (Khan and Drewes, 2004; Owira and Ojewole, 2009; Matyanga et al., 2020) depletes local populations, especially around urban centres (Dold and Cocks, 2002; Mofekeng et al., 2020). Plants with large corms are becoming less available in the wild because of overharvesting (Williams et al., 2007).

\subsection{Study site and experimental design}

The experiment was conducted, under light hail netting, at the N.M. Tainton arboretum on the Pietermaritzburg campus of the University of KwaZulu-Natal, South Africa (mean annual rainfall $=844 \mathrm{~mm}$; mean daily temperature in hottest months $=28.2^{\circ} \mathrm{C}$; mean daily minimum winter temperature in coolest months $=2.9^{\circ} \mathrm{C}$ ). Hypoxis hemerocallidea plants obtained from a commercial nursery were grown in 14 litre pots in an organic (> 6\% C; $0.55 \% \mathrm{~N})$, slightly acidic $(\mathrm{pH}=5.53)$ nutrient-rich growing medium $\left(\mathrm{P}=81 \mathrm{mg} \mathrm{l}^{-1}, \mathrm{~K}=156 \mathrm{mg}\right.$ $\mathrm{I}^{-1}, \mathrm{Ca}=2960 \mathrm{mg} \mathrm{l}^{-1}, \mathrm{Mg}=410 \mathrm{mg} \mathrm{l}^{-1}$; Manson et al., 2020) in order not to limit their growth. During the summer growing season (2019-2020), pots were watered to saturation on two occasions when no rainfall was received during hot periods. Because rainfall was low $1<20$ $\mathrm{mm}$ ) during the following spring (2020), all plants were given addition water at the end of winter (to initiate regrowth) and weekly in September.

The experiment comprised a full $2 \times 2$ factorial pot trial arranged in a completely randomised design with five replicate plants of $H$. hemerocallidea per treatment combination $(n=20)$. The treatment factors were frequent defoliation (clipped, unclipped) and spring sunlight growing conditions (dark, full light).

Defoliation was implemented during the first growing season (2019-2020) by clipping all above ground material at a height of $80 \mathrm{~mm}$ above the soil surface to remove most of the photosynthetic leaf surface, resulting in a mean defoliation intensity of $84 \%$ (77.8-87.1\%) reduction in the height of the tallest leaf. Plants were clipped six times, at a mean defoliation interval of 30 days, with shorter between clipping in the summer growing season 
(17-25 days) and longer intervals in autumn (60 days). The first defoliation was at the beginning of December 2019 and the sixth defoliation was in June 2020. Total above-ground phytomass was harvested at ground level towards the end of winter (23 July 2020) to assess the effect of defoliation on plant performance during the first season.

The carry-over effect of defoliation was assessed by measuring regrowth during the following spring (August - October 2020) with plants growing in full sunlight or under ventilated light-proof boxes that restrict light but allow air circulation for plant growth (Edwards, 1965). Plants regrowing in the dark have to rely on stored energy reserves, i.e. corms in the case of $H$. hemerocallidea, whereas those in full sunlight also sequester additional carbon via concurrent photosynthesis; a comparison of their relative vigour indicates the extent to which reserves are available or have been depleted by defoliation during the previous growing season (Muzzell and Booysen, 1995; Peddie et al., 1995; Ripley et al., 2015).

\subsection{Growth performance measures}

Total plant above-ground dry matter (AGDM) yield at the end of the first growing season was measured as the sum of all material removed by each clipping and the final standing phytomass (leaves plus inflorescences) in winter. At the end of spring (6 October 2020) all above-ground phytomass was harvested to ground level and corms were excavated. Roots could not be separated from the polystyrene material used at the bottom of pots for drainage and were therefore not included in below-ground biomass measures. All phytomass was dried to constant mass in an oven at $60^{\circ} \mathrm{C}$. Additional plant measures taken before each clipping, at the end of the growing season (in June 2020), and in the following spring (October 2020) were: number of leaves, number of inflorescences, and height of the tallest leaf, which was typically marginally longer than the other leaves on a plant.

\section{Statistical analyses}

The effect of defoliation (clipped vs. control) on plant performance (number of leaves, number of inflorescences, leaf height, and AGDM) measured at the end of the first growing season was tested with t-tests for unequal variance. Two-way analysis of variance (ANOVA) was used to assess the main and interaction effects of previous season defoliation (unclipped vs clipped) and spring regrowth light conditions (restricted vs. full light) on the 
above-mentioned plant measures and dry corm mass. Post-hoc comparisons across factor means were conducted only when interaction effects were significant $(p \leq 0.05)$. Linear regression was used to assess the relation between AGDM, number of leaves, number of inflorescences, and corm dry mass at the end of spring.

\section{Results}

\subsection{Treatment season responses}

Unclipped control plants grew steadily from an initial maximum leaf height of $48.4 \pm 5.15 \mathrm{~cm}$ to reach a peak height of $66.0 \pm 2.02 \mathrm{~cm}$ in early February, diminishing somewhat thereafter to $61.2 \pm 1.70 \mathrm{~cm}$ at the end of the growing season in early June (Fig. 1). Clipped plants were as tall as control plants at the start $(53.8 \pm 2.16 \mathrm{~cm})$ and the end $(65.0 \pm 2.74 \mathrm{~cm})$ of the measuring period in early December and early June, respectively. Clipped plants regrew to a height of $36.0 \pm 0.87 \mathrm{~cm}$ ( $63.8 \%$ of control plants) after the first defoliation and between 50.0-51.6 cm (75.8-82.2\% of control plant height) after the second, third, and fourth clipping (Fig. 1). The mean clipping intensity at a fixed height of $8 \mathrm{~cm}$ above soil level was $13.5 \%$ (12.1-16.5\%) of control plant heights measured at the same times. At the end of the growing season, control plants had a mean of $20.5 \pm 2.32 \%$ dry leaves ( $>50 \%$ of a leaf brown) but all leaves on all plants had completely senesced by the final harvest date towards the end of July. In contrast, all leaves of all clipped plants remained completely green until June and five plants still retained green leaves in July.

Although clipped plants regrew to the same height $(t=0.493, p=0.630)$ as controls after the final defoliation, they had $16.3(-59.7 \%)$ fewer leaves $(t=7.043, p<0.0001)$ and $15(-$ 84.3\%) fewer flowers ( $t=6.061, p=0.0001)$, on average, than unclipped plants at the end of the growing season (Table 1). Clipping did not reduce the total yield (offcuts plus final harvest) of above-ground dry matter (AGDM) compared to the control $(t=0.147, p=0.885)$ plants (Table 1).

INSERT FIG. 1

INSERT TABLE 1

\subsection{Spring regrowth responses}


No interactive effects $(p>0.05)$ of previous-season defoliation and light availability on spring regrowth were evident for any of the plant parameters measured in early October (Table 2). Light regime during spring did, however, have a consistent effect, irrespective of clipping history, on maximum leaf height and inflorescence number with leaves being etiolated by $38 \%$ (13.1 mm; $p=0.0004)$ and plants having $22.4 \%(-1.5)$ fewer inflorescences $(p=0.0246)$ in the dark than in full sunlight (Table 2; Fig. 2). Restricted light conditions tended to reduce leaf number, but not significantly so $(p=0.0907)$, but did not affect $(p>$ 0.50) AGDM nor corm dry mass (Table 2; Fig. 2).

Clipping five times during the preceding growing season consistently reduced inflorescence number $(-2.9)$ by $39.2 \%(p=0.0002)$ compared to undefoliated controls but did not influence the number of leaves $(p=0.308)$ nor their maximum height $(p=0.526)$ at the end of spring (Table 2; Fig. 2). Above-ground yield was reduced by one-third (-5.27 g; $p=0.0051$ ) and corm mass was more than halved $(-54.4 \% ;-148.4 \mathrm{~g} ; \mathrm{p}=0.0016)$ by frequent clipping during the previous season (Table 2; Fig. 2).

\section{INSERT TABLE 2}

INSERT FIG. 2

At the end of spring, there was a positive correlation between AGDM yield and corm mass of $H$. hemerocallidea plants $(r=0.552, p=0.012)$. Above-ground dry matter varied the most for plants with small corms (Fig. 3). Number of inflorescences $(r=0.461, p=0.041)$, but not leaf number $(r=0.139 ; p=0.559)$, was positively correlated with corm dry mass.

INSERT FIG. 3

\section{Discussion}

This study set out to explore a possible mechanism to explain the demise of many mesic grassland forbs in overgrazed mesic grassland by examining the immediate and seasonal carry-over effects of recurrent defoliation on the above- and below-ground performance of a mesic grassland geophytic forb, $H$. hemerocallidea. It was hypothesised that frequent leaf damage by herbivory, simulated by severe clipping, would reduce above-ground plant growth and that the corms (the USO) of the H. hemerocallidea would be diminished by 
recurrent defoliation because of reduced carbon supply from leaves for storage and a greater demand for stored reserves for regrowth. Key results in support of this hypothesis were that plants were largely resilient to repeated, severe defoliation in the first season of cutting but regrowth was reduced in the following spring. Corm mass was more than halved by defoliation, indicating that USOs ostensibly protected underground are vulnerable to adverse effect of disturbance to aerial plant parts. Herbivore induced depletion of USOs could, therefore, potentially threaten the persistence of forbs in grassland chronically disturbed by heavy grazing or frequent mowing.

The importance of USOs for supplying energy and other resources to forb species that need to resprout after a dormant period was supported by the results of this experiment. Hypoxis hemerocallidea plants that grew under restricted light conditions, when they had to fully rely on stored energy reserves rather than on concurrent photosynthesis for spring leaf production, were able to match the total growth of plants that resprouted in full light, although their flower production was somewhat curtailed (-22.4\%). Forbs that have access to a substantial buried bud bank (Klimešová and Klimes, 2007) and a store of resources can initiate growth sooner than grasses, thereby exploiting the limited opportunity to sequester carbon, grow, spread, and produce flowers, before light becomes limiting because of grass canopy closure (Bayer, 1955; Lammont and Downes, 2011). Bews and Vanderplank (1930) found that such spring growth does not appear to significantly deplete NSCs (primarily starch) in the corms of $H$. hemerocallidea dug up periodically from the field and questioned the value of stored energy reserves for regrowth. They did, however, note that other resources such as minerals and water (Chapin et al., 1990; da Silva and Rossatto, 2019) are also supplied by the USO (Bews and Vanderplank, 1930). Plants may continue to draw up nitrogen and phosphorus into leaves after they have ceased mobilising NSCs from the USO to initiate regrowth (Rosenthal and Kotanen, 1994). Buried storage organs also enable grassland forbs to escape frost, tolerate temporary drought during the dry autumn to winter period, and survive fires that occur commonly during or shortly after the dormant period (Dafni et al. 1981; Ruiters et al., 1993; Proches et al. 2005; Clarke et al. 2013). Directing growth to protected storage organs, does therefore, appear to be a key plant survival trait for environments where there is a high, persistent risk of complete loss of leaves through 
senescence or fire during the dry season (Ott et al., 2019; Siebert et al., 2019; Ottaviani et al., 2020).

Underground stores also enable plants to tolerate partial or complete damage or loss of leaves by mowing, insect folivory, or mammalian herbivory when they are actively growing (Strauss and Agrawal, 1999; Tiffin, 2000; Thomas et al., 2017). The substantial corm of $H$. hemerocallidea likely enabled it to fully compensate for biomass lost through frequent, severe defoliation during the first summer growing season by providing resources for repeated regrowth. Such a compensatory growth response indicates that, although the imposed defoliation regime would have limited carbon sequestration, the overall availability of carbon to the plant for repeated regrowth was not limiting (Wise and Abrahamson, 2005). Leaf and flower numbers, were, however, significantly impacted by defoliation, possibly because of a prioritisation of leaf extension and expansion over initiation of new leaf and floral primordia in the corm (Shefferson et al., 2006).

The effect of growing-season disturbance intensity, frequency, and timing on biomass allocation and growth of geophytic forbs has, unlike for grasses (Briske and Richards, 1995; Ferraro and Oesterheld, 2002), received very little attention. Frequent mowing suppresses above- and below-ground forb biomass (Ottaviani et al., 2021) and forb species diversity (Fynn et al., 2014). Generally, longer periods between defoliations (i.e., low defoliation frequency) reduce the negative effect of defoliation on plants (Ferraro and Oesterheld, 2002) by allowing leaf area to accumulate, roots to grow and stores to be replenished and accumulated (Bayer, 1955; Chapin et al., 1990; Tyler and Borchert, 2003). The latter part of the growing season from late summer into autumn, when growth rates slow under declining temperatures but photosynthesis continues, could be a crucial period for storage (Chapin et al., 1990) and recycling of nutrients from senescing leaves down to USOs (Ruiters et al., 1993). The seasonal carbohydrate and nutrient dynamics of $H$. hemerocallidea and other mesic grassland geophytes in relation to disturbance have not been examined but affording plants an opportunity to recuperate and accumulate excess non-structural carbohydrate reserves, especially starch, in autumn could enhance their ability to rapidly resprout in the following spring (Janeček et al., 2015; Martínez-Vilalta et al., 2016). Clipped plants of $H$. hemerocallidea retained a higher proportion of green leaf than unclipped plants during autumn, perhaps contributing to their ability to recover their stature and biomass 
production after frequent defoliations in summer. This resilience displayed by $H$. hemerocallidea under summer defoliation was, however, not repeated in the following spring when previously clipped plants produced a third-less above-ground biomass than unlipped plants.

The most marked impact of single season of clipping on $\mathrm{H}$. hemerocallidea was the loss of more than half of its corm mass. Ottaviani et al. (2021) also observed far lower (by > 70\%) rhizome biomass in temperate grassland mown twice versus grassland mown once annually. In that study, below- and above-ground biomass scaled linearly (Ottaviani et al. (2021), similar to the positive linear relation between corm size and spring biomass production in $H$. hemerocallidea (Fig. 3). Lubbe et al. (2021) also found a significant positive correlation between below-ground stored carbohydrate concentration and leaf economic traits, particularly plant height, of 78 temperate herbs. These results on the positive influence of USO size on growth accord with widespread knowledge in the horticultural industry that plants with large bulbs or tubers produce are the most vigorous, producing the highest number of leaves, flowers, and clonal offspring (e.g. Rees, 1969; Ahmad et al., 2009; Kapczyńska, 2014). Tuber and bulb size or mass is a general indication of the total carbon pool available for growth and reproduction (Werger and Huber, 2006; Lee et al., 2016). Therefore, a large reduction in the mass of USOs of a grassland forb resulting from frequent reduction of photosynthetic surfaces area during the growing season, as observed in this trial, would reduce the plant's ability to recuperate and its long-term resilience to recurrent leaf disturbance (Canadell and López-Soria, 1998; Tolsma, 2002).

Reproductive buds are also borne on the USO of geophytes (Klimešová and Klimes, 2007; Pausas et al., 2018), and any diminution of individual storage organs by grazing (Qian et al., 2017) could reduce the potential for forbs to reproduce sexually or to spread through clonal growth (Klimešová and Klimes 2007). Inflorescence production was the growth component of $H$. hemerocallidea most markedly reduced by clipping, both during the season of clipping and in the following spring; smaller corms bore significantly fewer inflorescences. This suggests that initiation and extension of floral buds on the corm was not prioritised in the allocation of resources mobilised from the USO for regrowth (Chapin et al., 1990). Seed production in $\mathrm{H}$. hemerocallidea is high but germination is inherently poor because of a hard seed coat and embryo dormancy (Hammerton and van Staden, 1988; Katerere, 2015). 
Seedling emergence and successful recruitment by mesic grasslands forbs is generally very low (Uys, 2006) and seedlings could be vulnerable to the grazing and trampling of herbivores (Scott-Shaw and Morris, 2006; Chamane et al., 2017b). Consequently, the already tight demographic bottleneck of forbs could be narrowed by herbivory, reducing the likelihood of new recruits. Hypoxis hemerocallidea plants can produce cormlets from corm buds, with medium to large corms potentially producing the most daughter corms (Mofokeng et al., 2018). However, adults have not been noted to occur in clumps (Pooley, 1998), which suggests that clonal expansion of populations is not typical.

Taken together, results of this trial indicate that growing-season damage to leaves, such as by intensive mowing or by the grazing and/or trampling of livestock can reduce the shortterm resilience, and potentially long-term persistence of, geophytic forbs such as $H$. hemerocallidea in disturbed mesic grassland. Use of stored reserves for regrowth after repeated, intense disturbance during the growing season depletes USOs while diminished USOs reduce the potential for future shoot growth and reserve replenishment (Ottaviani et al., 2021). This recursive, negative feedback on plant growth may result in progressive rundown of vigour and above- and below-ground plant biomass if grazing and trampling continues unabated (Turner et al., 1993). Erect forbs would be most vulnerable to long-term recurrent leaf damage or loss (Fynn et al., 2004; Chamane et al., 2017a; Morris and ScottShaw, 2019). Gradual attrition of USOs and bud banks under chronic herbivory could, therefore, be the mechanism whereby populations of mesic grassland forbs are extirpated or severely reduced through overgrazing (Scott-Shaw and Morris, 2015).

This defoliation pot experiment on $\mathrm{H}$. hemerocallidea has provided proof of the principle that recurrent growing-season disturbance to aerial parts of a geophytic forb negatively impacts buried storage organs and spring recovery growth, with a potential impact on its longevity in highly disturbed environments. The application of this principle to other geophytic forb species in a variety of environments would depend on several factors. In grazed fields, forbs are likely to experience less frequent and intense defoliation - with perhaps only partial leaf damage - than the experimental levels imposed upon $H$. hemerocallidea. Therefore, the short-term impact of herbivores on shoots and USOs would probably be smaller than that observed in this trial. However, $H$. hemerocallidea has a substantial corm that might better tolerate frequent defoliation than the smaller USOs of 
those mesic grassland forbs that resprout from woody rootstocks, thickened (e.g., fusiform) roots, or rhizomes (Pooley, 1998; Uys, 2006); such species could thus be especially vulnerable to herbivory. The capacity for compensatory growth is generally highest for plants growing in fertile soils (Wise and Abrahamson, 2005), such as that used in this trial where nutrients were not limiting. On less fertile soils and in drier, less productive environments, plants would be less tolerant of recurrent loss of tissue (Janeček et al, 2015; Morris, 2016) and, consequently, more likely to be severely impacted by sustained disturbance. Further research is thus required on the seasonal and carry-over effects of leaf disturbance on forbs with a range of USO types and sizes, their long-term response to herbivory, and management options for sustaining the abundance and diversity of forbs in mesic grassland.

Careful management of extant populations of forbs in mesic grassland is required because once eliminated from primary grassland, such long-lived perennials do not readily reestablish (Zaloumis and Bond, 2016; Buisson et al., 2019) even after many centuries of recovery (Nerlekar et al., 2020). Three key management interventions are required to maintain forbs in grazed mesic grassland: regular fire, lenient grazing or mowing, and periodic rests. Without regular disturbance by burning during the dormant season or early spring, forb diversity, composition, and underground bud banks will decline (Uys et al., 2004; Fynn et al., 2005; Fidelis et al., 2014; Kirkman et al., 2014; Gordijn et al., 2018). Forb biomass and diversity can also be maintained by infrequent summer mowing (Fynn et al., 2004; Ottaviani et al., 2021). Heavy stocking with concentrated herds of livestock is not a safe alternative to fire or mowing, as advocated by proponents of high-density grazing systems (e.g. Savory and Butterfield, 2016) because hooves repeatedly damage living leaves (Chamane et al., 2017b), eventually leading to the demise of many forbs (Scott-Shaw and Morris, 2015). In contrast, moderate livestock stocking rates and densities, especially when coupled with controlled burning (O'Connor et al., 2010; SANBI, 2014; Scott-Shaw and Morris, 2015; Joubert et al., 2017) are sustainable without the risk of damaging forbs and ecosystem processes. However, even lightly stocked mesic grassland needs to be afforded a full-season rest (deferment) from grazing every few years to restore the vigour of grazed palatable grasses (Kirkman, 2002; McDonald et al., 2019). Such periods of uninterrupted growth would likely also benefit forbs which have experienced extensive leaf damage and 
USO depletion over several consecutive years by allowing them to replenish their reservoir of stored reserves (Janeček et al., 2015; Martínez-Vilalta et al., 2016) and to flower and set seed (Uys, 2016).

\section{Conclusion}

Mesic grassland forbs are fire-adapted but not grazing resistant. Their underground storage organs (USOs) protect them from frost and regular dormant-season fires, but, as this research demonstrates, below-ground plant organs are sensitive to above-ground disturbance in the growing season. Recurrent damage to growing leaves can negatively impact forbs, markedly diminishing the biomass of their USO and their consequent ability to support resprouting in spring. Therefore, the regenerative and resource storage organs of long-lived geophytic forbs located underground are not safe from excessive mowing or herbivory (cf. Klimešová et al., 2018). The observed marked negative carry-over effect of frequent defoliation of $H$. hemerocallidea on its subsequent regrowth and corm size portends dwindling resilience and potentially lower longevity of plants under unrelenting intense disturbance. A substantial reduction in flowering in perennial mesic grassland geophytic herbs could be a useful bellwether of declining vigour in forbs because inflorescence production is highly sensitive to herbivory.

Management of species-rich mesic grassland needs to aim to minimise repeated, severe damage to the green above-ground biomass of forbs. Management during the growing season should, therefore, be lenient and high stocking densities should be avoided. Infrequent summer mowing or grazing at moderate stocking rates and densities combined with fire and periodic full season resting are recommended to maintain the vigour and resilience of forbs in mesic grassland.

\section{Acknowledgements}

I am grateful to Welcome Ngcobo who helped set up and maintain the experiment, Anita Morris for her help in treatment application and data collection, and Nicky Findlay for the soil analysis. 


\section{References}

Ahmad, I., Ahmad, T., Asif, M., Saleem, M., Akram, A., 2009. Effect of bulb size on growth, flowering and bulbils production of tuberose. Sarhad Journal of Agriculture 25, 391-398.

Bayer, A.W., 1955. The ecology of grasslands, in: Meredith, D. (Ed.), The Grasses and Pastures of South Africa. CNA, Cape Town, pp. 539-550.

Bews, J.W., Vanderplank, J.E., 1930. Storage and other carbohydrates in a Natal succulent and a Natal geophyte and their behaviour before, during, and after the winter resting season. Annals of Botany 44, 689-719.

Bond, W.J., Midgley, G.F., Woodward, F.I., 2003. What controls South African vegetation climate or fire? South African Journal of Botany 69, 79-91.

Bond, W.J., Parr C.L., 2010. Beyond the forest edge: ecology, diversity and conservation of the grassy biomes. Biological Conservation 143, 2395-2404.

Bond, W.J., Zaloumis, N.P., 2016. The deforestation story: testing for anthropogenic origins of Africa's flammable grassy biomes. Philosophical Transactions of the Royal Society B: Biological Sciences 371, 20150170.

Briske, D.D., Boutton, T.W., Wang, Z., 1996. Contribution of flexible allocation priorities to herbivory tolerance in C4 perennial grasses: an evaluation with $13 \mathrm{C}$ labelling. Oecologia 105, 151-159.

Briske, D.D., Richards, J.H., 1995. Plant responses to defoliation: a physiological, morphological and demographic evaluation. Department of Rangeland Ecology and Management, Texas A\&M University, College Station, TX. Downloaded from https://agrilifecdn.tamu.edu/briske/files/2014/03/Briske-Richards-SRM-CHAPTER95.pdf

Buisson, E., Le Stradic, S., Silveira, F.A., Durigan, G., Overbeck, G.E., Fidelis, A., Fernandes, G.W., Bond, W.J., Hermann, J.M., Mahy, G., Alvarado, S.T., 2019. Resilience and restoration of tropical and subtropical grasslands, savannas, and grassy woodlands. Biological Reviews 94, 590-609.

Canadell, J., López-Soria, L., 1998. Lignotuber reserves support regrowth following clipping of two Mediterranean shrubs. Functional Ecology 12, 31-38.

Chamane, S., Kirkman, K.P., Morris, C., O'Connor, T.G., 2017a. What are the long-term effects of high-density, short-duration stocking on the soils and vegetation of mesic grassland in South Africa? African Journal of Range \& Forage Science 34, 111-121.

Chamane, S., Kirkman, K. ., Morris, C., O'Connor, T.G., 2017b. Does high-density stocking affect perennial forbs in mesic grassland? African Journal of Range \& Forage Science 34, 133-142. 
Chamane, S., Kirkman, K.P., Morris, C., O'Connor, T.G., 2019. Response of three mesic South African perennial grassland forbs to defoliation and competition. African Journal of Range \& Forage Science, 36(4), 191-195.

Chapin III, F.S., Schulze, E.D., Mooney, H.A., 1990. The ecology and economics of storage in plants. Annual Review of Ecology and Systematics 21, 423-447.

Clarke, P.J., Lawes, M.J., Midgley, J.J., Lamont, B.B., Ojeda, F., Burrows, G.E., Enright, N.J., Knox, K.J.E., 2013. Resprouting as a key functional trait: how buds, protection and resources drive persistence after fire. New phytologist 197, 19-35.

Cole, D.N., 1995. Experimental trampling of vegetation. II. Predictors of resistance and resilience. Journal of Applied Ecology 32, 215-224

Cowling, R.M., Hilton-Taylor, C., 1997. Phytogeography, flora and endemism, in: Cowling, R.M., Richardson, D.M., Pierce, S.M. (Eds.), Vegetation of Southern Africa. Cambridge University Press, Cambridge, UK, pp. 43-61.

Dafni, A., Cohen, D., Noy-Mier, I., 1981. Life-cycle variation in geophytes. Annals of the Missouri Botanical Garden 68, 652-660.

Danckwerts, J.E., Gordon, A.J., 1990. Partitioning, storage and remobilization of $14 \mathrm{C}$ assimilated by Themeda triandra Forssk. Journal of the Grassland Society of Southern Africa 7, 97-105.

da Silva, B.H.P., Rossatto, D.R., 2019. Are underground organs able to store water and nutrients? A study case in non-arboreal species from the Brazilian Cerrado. Theoretical and Experimental Plant Physiology 31, 413-421.

Dold, A.P., Cocks, M.L., 2002. The trade in medicinal plants in the Eastern Cape Province, South Africa. South African Journal of Science 98, 589-597.

Edwards, P.J., 1965. The construction and use of light-proof boxes in grassland research work. Proceedings of the IXth International Grassland Congress, 1483-1485.

Everson, T.M., Everson, C.S., Dicks, H.M., Poulter, A.G., 1988. Curing rates in the grass sward of the Highland Sourveld in the Natal Drakensberg. South African Forestry Journal 145, 1-8.

Ferraro, D.O., Oesterheld, M., 2002. Effect of defoliation on grass growth. A quantitative review. Oikos 98, 125-133.

Fidelis, A., Appezzato-da-Glória, B., Pillar, V.D., Pfadenhauer, J., 2014. Does disturbance affect bud bank size and belowground structures diversity in Brazilian subtropical grasslands? Flora-Morphology, Distribution, Functional Ecology of Plants 209, 110-116.

Fynn, R.W., Morris, C.D., Edwards, T.J., 2004. Effect of burning and mowing on grass and forb diversity in a long-term grassland experiment. Applied Vegetation Science 7, 1-10.

Fynn, R.W., Morris, C.D., Edwards, T.J., 2005. Long-term compositional responses of a South African mesic grassland to burning and mowing. Applied Vegetation Science 8, 5-12. 
Gordijn, P.J., Everson, T.M., O'Connor, T.G., 2018. Resistance of Drakensberg grasslands to compositional change depends on the influence of fire-return interval and grassland structure on richness and spatial turnover. Perspectives in Plant Ecology, Evolution and Systematics 34, 26-36.

Hammerton, R.D., van Staden, J., 1988. Seed germination of Hypoxis hemerocallidea. South African Journal of Botany 54, 277-280.

Janeček, Š., Bartušková, A., Bartoš, M., Altman, J., de Bello, F., Doležal, J., Latzel, V., Lanta, V., Lepš, J., Klimešová, J., 2015. Effects of disturbance regime on carbohydrate reserves in meadow plants. AoB Plants, 7, plv123.

Jewitt, D., Goodman, P.S., Erasmus, B.F., O'Connor, T.G., Witkowski, E.T., 2015. Systematic land-cover change in KwaZulu-Natal, South Africa: implications for biodiversity. South African Journal of Science 111, 01-09.

Joubert, L., Pryke, J.S., Samways, M.J., 2017. Moderate grazing sustains plant diversity in Afromontane grassland. Applied Vegetation Science 20, 340-351.

Kapczyńska, A., 2014. Effect of bulb size on growth, flowering and bulb formation in lachenalia cultivars. Horticultural Science 41, 89-94.

Khan, F., Drewes, S.E., 2004. The African potato (Hypoxis hemerocallidea): a chemicalhistorical perspective. South African Journal of Science 100, 425-430.

Kirkman, K.P., 2002. The influence of various types and frequencies of rest on the production and condition of sourveld grazed by sheep or cattle. 1. Proportional species composition. African Journal of Range \& Forage Science 19, 55-62.

Kirkman, K.P., Collins, S.L., Smith, M.D., Knapp, A.K., Burkepile, D.E., Burns, C.E., Fynn, R.W., Hagenah, N., Koerner, S.E., Matchett, K.J., Thompson, D.I., 2014. Responses to fire differ between South African and North American grassland communities. Journal of Vegetation Science 25, 793-804.

Klimešová, J., Klimes, J., 2007. Bud banks and their role in vegetative regeneration - a literature review and proposal for simple classification and assessment. Perspectives in Plant Ecology, Evolution and Systematics 8, 115-129.

Klimešová, J., Martínková, J., Ottaviani, G., 2018. Belowground plant functional ecology: towards an integrated perspective. Functional Ecology 32, 2115-2126.

Klimešová, J., Martínková, J., Pausas, J.G., de Moraes, M.G., Herben, T., Yu, F.H., Puntieri, J., Vesk, P.A., de Bello, F., Janeček, Š., Altman, J., 2019. Handbook of standardized protocols for collecting plant modularity traits. Perspectives in Plant Ecology, Evolution and Systematics 40, 125485.

Lamont, B.B., Downes, K.S., 2011. Fire-stimulated flowering among resprouters and geophytes in Australia and South Africa. Plant Ecology 212, 2111-2125.

Lee, J., Ha, I., Kim, H., Choi, S., Lee, S., Boyhan, G.E., 2016. Regional differences in onion bulb quality and nutrient content, and the correlation between bulb characteristics and storage loss. Horticultural Science and Technology 34, 807-817. 
Lubbe, F.C., Klimeš, A., Doležal, J., Jandová, V., Mudrák, O., Janeček, Š., Bartušková, A., Klimešová, J., 2021. Carbohydrate storage in herbs: the forgotten functional dimension of the plant economic spectrum. Annals of Botany mcab014, https://doi.org/10.1093/aob/mcab014

Manson, A.D., Bainbridge, S.H.,Thibaud G.R., 2020. Methods used for analysis of soils and plant material by Analytical Services at Cedara. KZN Agri-Report No. N/A/2020/07, KwaZuluNatal Department of Agriculture and Rural Development, Pietermaritzburg, South Africa.

Martínez-Vilalta, J., Sala, A., Asensio, D., Galiano, L., Hoch, G., Palacio, S., Piper, F.I., Lloret, F., 2016. Dynamics of non-structural carbohydrates in terrestrial plants: a global synthesis. Ecological Monographs 86, 495-516.

Martorell, C., Zepeda, V., Martínez-Blancas, A., García-Meza, D., Pedraza, F., 2017. A diversity world record in a grassland at Oaxaca, Mexico. Botanical Sciences 95, 1-7.

Matyanga, C.M., Morse, G.D., Gundidza, M. and Nhachi, C.F., 2020. African potato (Hypoxis hemerocallidea): a systematic review of its chemistry, pharmacology and ethno medicinal properties. BMC Complementary Medicine and Therapies 20, 1-12.

McDonald, S.E., Lawrence, R., Kendall, L., Rader, R., 2019. Ecological, biophysical and production effects of incorporating rest into grazing regimes: a global meta-analysis. Journal of Applied Ecology 56, 2723-2731.

Mofokeng, M.M., Kleynhans, R., Sediane, L.M., Morey, L., Araya, H.T., 2018. Propagation of Hypoxis hemerocallidea by inducing corm buds. South African Journal of Plant and Soil 35, 359-365.

Mofokeng, M.M., Araya, H.T., Amoo, S.O., Sehlola, D., du Plooy, C.P., Bairu, M.W., Venter, S., Mashela, P.W., 2020. Diversity and conservation through cultivation of Hypoxis in Africa - a case study of Hypoxis hemerocallidea. Diversity 12, 122. https://doi.org/10.3390/d12040122

Morris, C.D., 2004. Manage the grassland not just the grass. Grassroots: Newsletter of the Grassland Society of Southern Africa 14, 16-19.

Morris, C.D., 2016. Is the grazing tolerance of mesic decreaser and increaser grasses altered by soil nutrients and competition? African Journal of Range \& Forage Science 33, 235-245.

Morris, C.D., Everson, C.S., Everson, T.M., Gordijn, P.J., 2020. Frequent burning maintained a stable grassland over four decades in the Drakensberg, South Africa. African Journal of Range \& Forage Science 38, 39-52.

Morris, C.D., Scott-Shaw, R., 2019. Potential grazing indicator forbs for two mesic grasslands in South Africa. Ecological Indicators 107, 105611.

Muzzell, P.J., Booysen, P.DeV., 1969. The use of light-proof boxes for the measurement of plant vigour in cocksfoot (Dactylis glomeratal $L$ ) and lucerne (Medicago satival $L$ ).

Proceedings of the Annual Congresses of the Grassland Society of Southern Africa 4, 44-48.

Nerlekar, A.N., Veldman, J.W., 2020. High plant diversity and slow assembly of old-growth grasslands. Proceedings of the National Academy of Sciences 117, 18550-18556. 
O'Connor, T.G., 2005. Influence of land use on plant community composition and diversity in Highland Sourveld grassland in the southern Drakensberg, South Africa. Journal of Applied Ecology 42, 975-988.

O'Connor, T.G., Kuyler, P., Kirkman, K.P., Corcoran, B., 2010. Which grazing management practices are most appropriate for maintaining biodiversity in South African grassland? African Journal of Range \& Forage Science 27, 67-76.

Ott, J.P., Klimešová, J., Hartnett, D.C., 2019. The ecology and significance of below-ground bud banks in plants. Annals of Botany 123, 1099-1118.

Ottaviani, G., Lubbe, F.C., Lepš, J., Lisner, A., Martínková, J., Mudrák, O., Klimešová, J., 2021. Strong impact of management regimes on rhizome biomass across Central European temperate grasslands. Ecological Applications, e2317. https://doi.org/10.1002/eap.2317

Ottaviani, G., Molina-Venegas, R., Charles-Dominique, T., Chelli, S., Campetella, G., Canullo, R., Klimešová, J., 2020. The neglected belowground dimension of plant dominance. Trends in Ecology and Evolution 35, 763-766.

Owira, P.M., Ojewole, J.A., 2009. 'African potato'(Hypoxis hemerocallidea corm): a plantmedicine for modern and 21st century diseases of mankind? - A review. Phytotherapy Research 23, 147-152

Parrish, M.D., 2017. The influence of fire-grazer interactions on forb communities in a highveld grassland. MSc dissertation. University of Cape Town, South Africa.

Pausas, J.G., Lamont, B.B., Paula, S., Appezzato-da-Glória, B., Fidelis, A., 2018. Unearthing belowground bud banks in fire-prone ecosystems. New Phytologist 217, 1435-1448.

Peddie, G.M., Tainton, N.M., Hardy, M.B., 1995. The effect of past grazing intensity on the vigour of Themeda triandra and Tristachya leucothrix. African Journal of Range \& Forage Science 12, 111-115.

Pooley, E., 1998. A Field Guide to Wildflowers: KwaZulu-Natal and the Eastern Region. Natal Flora Publication Trust, Durban.

Procheş, Ş., Cowling, R.M., du Preez, D.R., 2005. Patterns of geophyte diversity and storage organ size in the winter-rainfall region of southern Africa. Diversity and Distributions 11, 101-109.

Qian, J., Wang, Z., Liu, Z., Busso, C.A., 2017. Belowground bud bank responses to grazing intensity in the Inner-Mongolia steppe, China. Land Degradation and Development 28, 822832.

Rees, A.R., 1969. Effect of bulb size on the growth of tulips. Annals of Botany 33, 133-142.

Ripley, B., Visser, V., Christin, P.A., Archibald, S., Martin, T., Osborne, C., 2015. Fire ecology of C3 and C4 grasses depends on evolutionary history and frequency of burning but not photosynthetic type. Ecology 96, 2679-2691.

Rosenthal, J.P., Kotanen, P.M., 1994. Terrestrial plant tolerance to herbivory. Trends in Ecology and Evolution 9, 145-148. 
Ruiters, C., McKenzie, B., Aalbers, J., Raitt, L.M., 1993. Seasonal allocation of biomass and resources in the geophytic species Haemanthus pubescens subspecies pubescens in lowland coastal fynbos, South Africa. South African Journal of Botany 59, 251-258.

SANBI, 2014. Grazing and Burning Guidelines: Managing Grasslands for Biodiversity and Livestock Production. Compiled by Lechmere-Oertel, R.G. South African National Biodiversity Institute, Pretoria. Downloadable from https://www.researchgate.net/publication/311674699 Burning and grazing for biodiversi ty in South Africa's grasslands

Savory, A., Butterfield, J., 2016. Holistic Management - A Commonsense Revolution to Restore Our Environment, third ed. Island Press, Washington DC.

Scott-Shaw, R., Morris, C.D., 2015. Grazing depletes forb species diversity in the mesic grasslands of KwaZulu-Natal, South Africa. African Journal of Range \& Forage Science 32, 2131.

Shefferson, R.P., Kull, T., Tali, K., 2006. Demographic response to shading and defoliation in two woodland orchids. Folia Geobotanica 41, 95-106

Siebert, F., Bombo, A.B., Archibald, S., Greve, M., Fidelis, A., 2019. Introducing bud bank and below-ground plant organ research to South Africa: Report on a workshop and the way forward. South African Journal of Science 115, 1-2.

Silveira, F.A., Arruda, A.J., Bond, W., Durigan, G., Fidelis, A., Kirkman, K., Oliveira, R.S., Overbeck, G.E., Sansevero, J.B.B., Siebert, F., Siebert, S.J., 2020. Myth-busting tropical grassy biome restoration. Restoration Ecology 28, 1067-1073.

Strauss, S.Y., Agrawal, A.A., 1999. The ecology and evolution of plant tolerance to herbivory. Trends in Ecology and Evolution 14, 179-185.

Thomas, S.M., Abbott, K.C., Moloney, K.A., 2017. Effects of aboveground herbivory on plants with long-term belowground biomass storage. Theoretical Ecology 10, 35-50.

Tiffin, P., 2000. Mechanisms of tolerance to herbivore damage: what do we know? Evolutionary Ecology 14, 523-536.

Tolsma, A.D., 2002. The effects of fire and grazing on the energy reserves of resprouting plants in Victoria's alpine grasslands. PhD dissertation. University of Melbourne, Australia.

Turner, C.L., Seastedt, T.R., Dyer, M.I., 1993. Maximization of aboveground grassland production: the role of defoliation frequency, intensity, and history. Ecological Applications $3,175-186$.

Tyler, C., Borchert, M., 2003. Reproduction and growth of the chaparral geophyte, Zigadenus fremontii (Liliaceae), in relation to fire. Plant Ecology 165, 11-20

Uys, R.G., 2006. Patterns of plant diversity and their management across South African rangelands; PhD dissertation. University of Cape Town, South Africa. 
Uys, R.G., Bond, W.J., Everson, T.M., 2004. The effect of different fire regimes on plant diversity in southern African grasslands. Biological Conservation 118, 489-499.

Valkó, O., Török, P., Matus, G., Tóthmérész, B., 2012. Is regular mowing the most appropriate and cost-effective management maintaining diversity and biomass of target forbs in mountain hay meadows? Flora 207, 303-309.

Werger, M.J., Huber, H., 2006. Tuber size variation and organ preformation constrain growth responses of a spring geophyte. Oecologia 147, 396-405.

White, L.M., 1973. Carbohydrate reserves of grasses: a review. Journal of Range Management 26, 13-18.

Wigley, B.J., Charles-Dominique, T., Hempson, G.P., Stevens, N., TeBeest, M., Archibald, S., Bond, W.J., Bunney, K., Coetsee, C., Donaldson, J., Fidelis, A., 2021. A handbook for the standardised sampling of plant functional traits in disturbance-prone ecosystems, with a focus on open ecosystems. Australian Journal of Botany 68, 473-531.

Williams, V.L., Balkwill, K., Witkowski, E.T.F., 2007. Size-class prevalence of bulbous and perennial herbs sold in the Johannesburg medicinal plant markets between 1995 and 2001. South African Journal of Botany 73, 144-155.

Williams, V.L., Raimondo, D., Crouch, N.R., Victor, J.E., Cunningham, A.B., Scott-Shaw, C.R., Lötter, M., Ngwenya, A.M., Singh, Y., 2019. Hypoxis hemerocallidea Fisch., C.A.Mey. \& AvéLall. National Assessment: Red List of South African Plants version 2020.1. Available online http://redlist.sanbi.org/species.php?species=1603-21 Accessed on 2020/12/02.

Wilson, J.B., Peet, R.K., Dengler, J., Pärtel, M., 2012. Plant species richness: the world records. Journal of Vegetation Science 23, 796-802.

Wise, M.J., Abrahamson, W.G., 2005. Beyond the compensatory continuum: environmental resource levels and plant tolerance of herbivory. Oikos 109, 417-428.

Zaloumis, N.P., Bond, W.J., 2016. Reforestation or conservation? The attributes of old growth grasslands in South Africa. Philosophical Transactions of the Royal Society B: Biological Sciences 371, 20150310. 
TABLE 1: The effect of frequent, severe clipping on plant growth parameters and yield of Hypoxis hemerocallidea at the end of the growing season. Significant $t$-values $(p \leq 0.05)$ are in bold.

\begin{tabular}{|c|c|c|c|c|c|c|}
\hline \multirow[t]{2}{*}{ Variable } & \multicolumn{2}{|c|}{ CLIPPED } & \multicolumn{2}{|c|}{ CONTROL } & \multirow[t]{2}{*}{ t-value } & \multirow[t]{2}{*}{ p-value } \\
\hline & Mean & se & Mean & se & & \\
\hline Number of leaves & 11.0 & 0.77 & 27.3 & 2.18 & 7.043 & 0.00002 \\
\hline Number of inflorescences & 2.8 & 0.63 & 17.8 & 2.39 & 6.061 & 0.00012 \\
\hline Maximum leaf height (mm) & 63.7 & 2.89 & 62.1 & 1.48 & 0.493 & 0.63042 \\
\hline Total above-ground dry matter yield (g) & 35.68 & 3.99 & 36.52 & 4.12 & 0.147 & 0.88510 \\
\hline
\end{tabular}


TABLE 2: Analysis of variance of the effects of clipping (clipped vs. unclipped) and light availability (dark vs. full sunlight) on the regrowth and yield of Hypoxis hemerocallidea in October measured at the end of the spring growth period. Significant t-values $(p \leq 0.05)$ are in bold.

\begin{tabular}{|c|c|c|c|c|c|c|c|c|c|c|c|}
\hline \multirow[t]{2}{*}{ Effect } & \multirow[t]{2}{*}{ d.f. } & \multicolumn{2}{|c|}{ No. leaves } & \multicolumn{2}{|c|}{ No. inflorescences } & \multicolumn{2}{|c|}{ Max. leaf height } & \multicolumn{2}{|c|}{ AGDM $^{1}$ yield } & \multicolumn{2}{|c|}{ Corm dry mass } \\
\hline & & $\mathbf{F}$ & $p$ & $\mathbf{F}$ & p & $\mathbf{F}$ & p & $\mathbf{F}$ & $p$ & $\mathbf{F}$ & $\mathbf{p}$ \\
\hline Light & 1 & 3.24 & 0.0907 & 6.16 & 0.0246 & 19.91 & 0.0004 & 0.37 & 0.5515 & 0.36 & 0.5569 \\
\hline Defoliation & 1 & 1.11 & 0.3077 & 23.04 & 0.0002 & 0.42 & 0.5261 & 10.54 & 0.0051 & 14.34 & 0.0016 \\
\hline Light $x$ Defoliation & 1 & 0.14 & 0.7132 & 1.34 & 0.2640 & 0.14 & 0.7132 & 0.70 & 0.4151 & 0.000039 & 1 \\
\hline
\end{tabular}




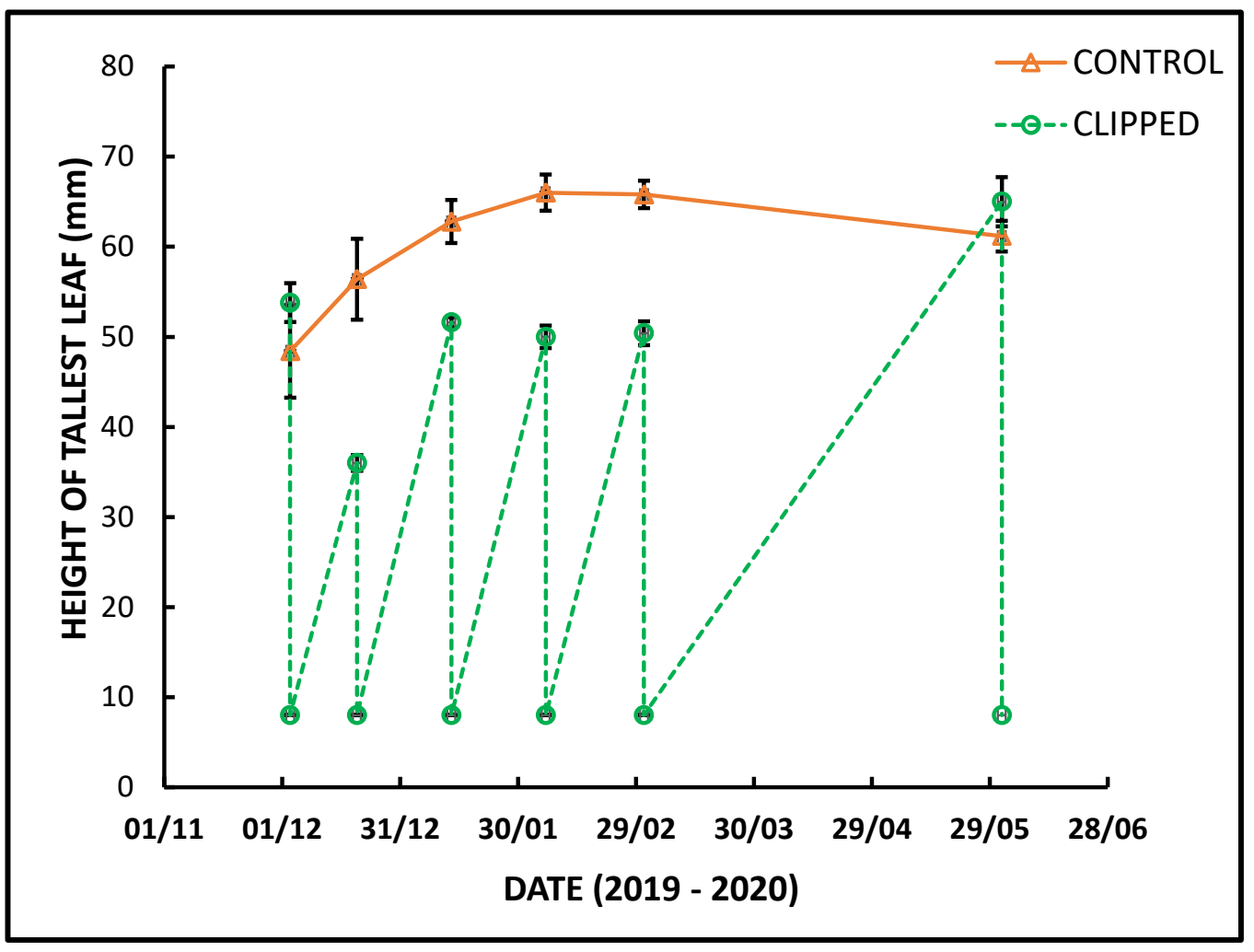

FIGURE 1: Seasonal changes in the mean ( \pm se) height of the tallest leaf of clipped and unclipped plants of Hypoxis hemerocallidea. 

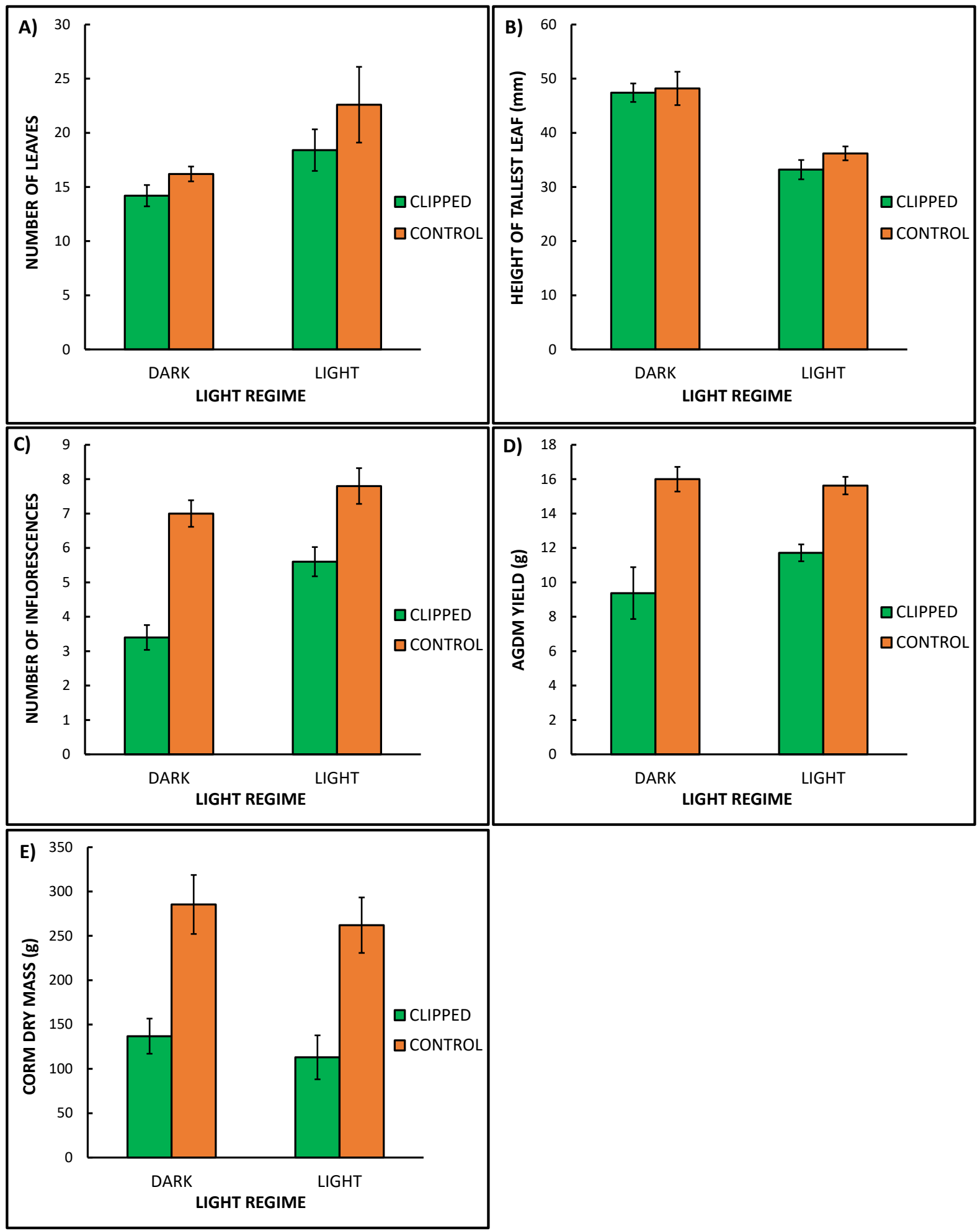

FIGURE 2:Mean ( \pm se) number of leaves (a), height of the tallest leaf (b), number of inflorescences (c), above-ground dry matter (AGDM) yield (d), and corm mass (e) of clipped and unclipped (control) plants of Hypoxis hemerocallidea at the end of spring in October. 


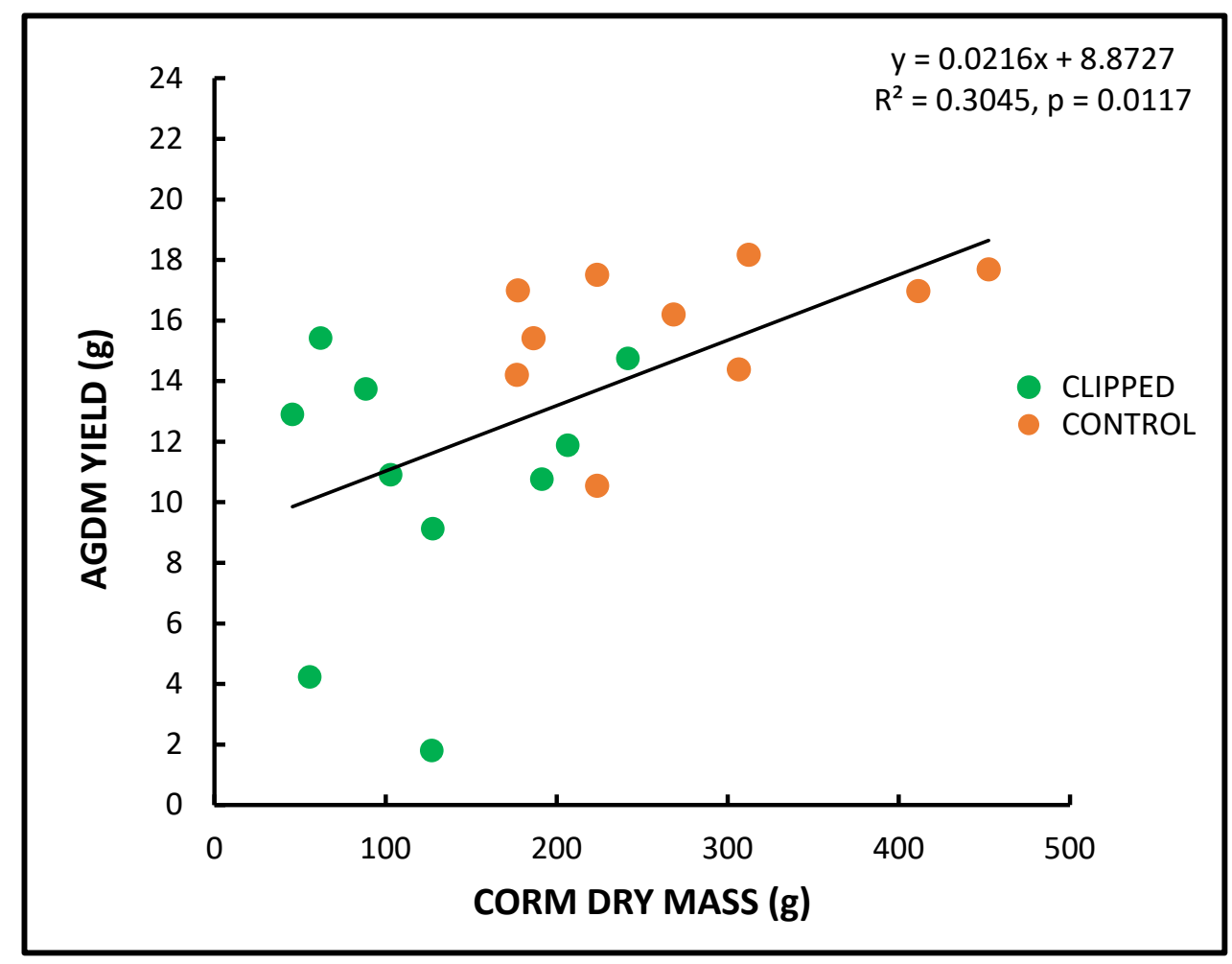

FIGURE 3: Linear regression of above-ground dry matter (AGDM) yield on corm dry mass of clipped and unclipped (control) plants of Hypoxis hemerocallidea at the end of the spring in October. 